\title{
Reconstructing the iron cycle from the horizontal distribution of metals in the sediment of Baldeggersee
}

\author{
Tobias Schaller ${ }^{1}$, H. Christoph Moor ${ }^{2}$ and Bernhard Wehrli ${ }^{1}$ \\ ${ }^{1}$ Limnological Research Center, Swiss Federal Institute for Environmental Sciences \\ and Technology (EAWAG) and Swiss Federal Institute of Technology (ETH), \\ CH-6047 Kastanienbaum, Switzerland \\ 2 Swiss Federal Laboratories for Materials Testing and Research (EMPA), CH-8600 Dübendorf, \\ Switzerland
}

Key words: Metal distribution, iron cycling, geochemical focusing.

\begin{abstract}
In Baldeggersee, the distributions of solid phase Fe, Mn, V, Cr, As and Mo were determined in different sediment strata, deposited under various deep-water oxygen conditions. Iron concentrations are correlated with water depth when an anoxic sediment is in contact with an oxic water column. Benthic redox gradients trigger iron transport towards the deepest site (geochemical focusing) and loss of iron from the shallower parts through the outflow. Fe cycling in the lake is inhibited by oxygen penetration into the sediment. Vanadium and arsenic can be used as tracers for the internal Fe cycle. Their distribution patterns are highly correlated with iron. In case of a stable oxycline in the deep water, Mo is enriched in the sediment and correlates with $\mathrm{Mn}$. The horizontal distribution patterns of Fe, V, As and the correlation of Fe and Mn with trace metals are promising proxy indicators for the reconstruction of deep-water oxygen conditions during deposition.
\end{abstract}

\section{Introduction}

The fate of minor and trace metals in lakes is determined by physical and biogeochemical processes in the sediment an the water column. Metal concentration patterns in the sediment reflect those processes and the geochemical conditions during deposition. Several recent studies reveal the potential of redox-sensitive metals as indicators for benthic oxygen concentrations (e.g. Calvert and Pederson, 1993; Emerson and Huested, 1991; Lapp and Balzer, 1993; Shaw et al., 1990; Thomson et al., 1995).

Eutrophic lakes are ideal systems to investigate the behavior of metals under different oxygen conditions, because fast mineralisation rates at the sediment-water interface lead to very steep redox gradients. Temporal and spatial variations of chemical gradients are coupled with a variety of processes which influence the fate of redox-sensitive elements. Reductive dissolution, diffusion and reprecipitation of 
iron (Baccini and Joller, 1981; Balistrieri et al., 1992a, b; Balistrieri et al., 1994; Davison, 1993; Sigg et al., 1987) drive internal metal cycles in the deep water. The cycles depend on benthic oxygen conditons and determine the horizontal distribution patterns of metal concentrations in the sediment. In a previous study (Schaller and Wehrli, 1997) we have shown that these mechanisms produce a geochemical focusing effect which determines the two-dimensional distribution of manganese.

The present study extends the analysis of geochemical focusing to iron and the trace metals $\mathrm{V}, \mathrm{Cr}$, As and Mo, which are strongly associated with the fate of iron particles (Belzile and Tessier, 1990; Cullen and Reimer, 1989; Hamilton-Taylor and Davison, 1995; Tessier, 1992; Wehrli, 1990). The chosen metals should not be strongly influenced by anthropogenic processes in the rural area of Baldeggersee (Berner and Berner, 1996; Benjamin and Honeyman, 1992). We analysed the horizontal concentration patterns in the sediments of Baldeggersee in three different sediment strata, which were deposited under contrasting oxygen conditions in the deep water. Two dimensional distributions of metals are discussed in terms of Fe cycling driven by changing redox conditons. Our study had two aims: (1) characteristic distribution patterns should be validiated as fingerprints for the reconstruction of deep-water oxygen conditions. (2) The spatial analysis should provide supporting information for a correct interpretation of the high-resolution time series from a freeze core taken at the deepest point of the lake (Schaller et al., 1997).

\section{Study site}

Baldeggersee is situated in the Swiss prealpine region at $463 \mathrm{~m}$ a.s.l., $16 \mathrm{~km}$ north of Lucerne (Stadelmann et al., 1984). Eutrophication began in Baldeggersee at the end of the last century (Züllig, 1982; Wehrli et al., 1997). In the deep flat plain, biogenic varves have been preserved since 1885 (Nipkow, 1928; Niessen and Sturm, 1987). The anoxic part of the sediment was first restricted to the deep flat plain in the center of the lake (Fig. 1). The stratigraphic analysis of sediment cores by Niessen and Sturm (1997) showed, that the anoxic water body increased in size during the first part of the century and reached a level of $40 \mathrm{~m}$ water depth during the $1940 \mathrm{~s}$. Oxygen profiles in the water column of Baldeggersee are available since 1948. The time series of average oxygen concentrations in the deep water (Wehrli et al., 1997) shows strong depletion of $\mathrm{O}_{2}$ in the hypolimnion during autumn in the period 1958-1982. The spring values in this period show average oxygen concentrations below $4 \mathrm{mg} \mathrm{l}^{-1}$, indicating incomplete mixing during spring overturn and a redox gradient within the deep water. During summer the water column was typically anoxic below $10 \mathrm{~m}$ depth. Since 1982 the lake has been artificially aerated (Stadelmann et al., 1984). The method has restored oxic conditions in the hypolimnion (Wehrli et al., 1997). A recent biological study has shown that the sediments are recolonized by Oligochaetae and Chironomidae down to a water depth of $55 \mathrm{~m}$ (Spengeler, unpublished results). 


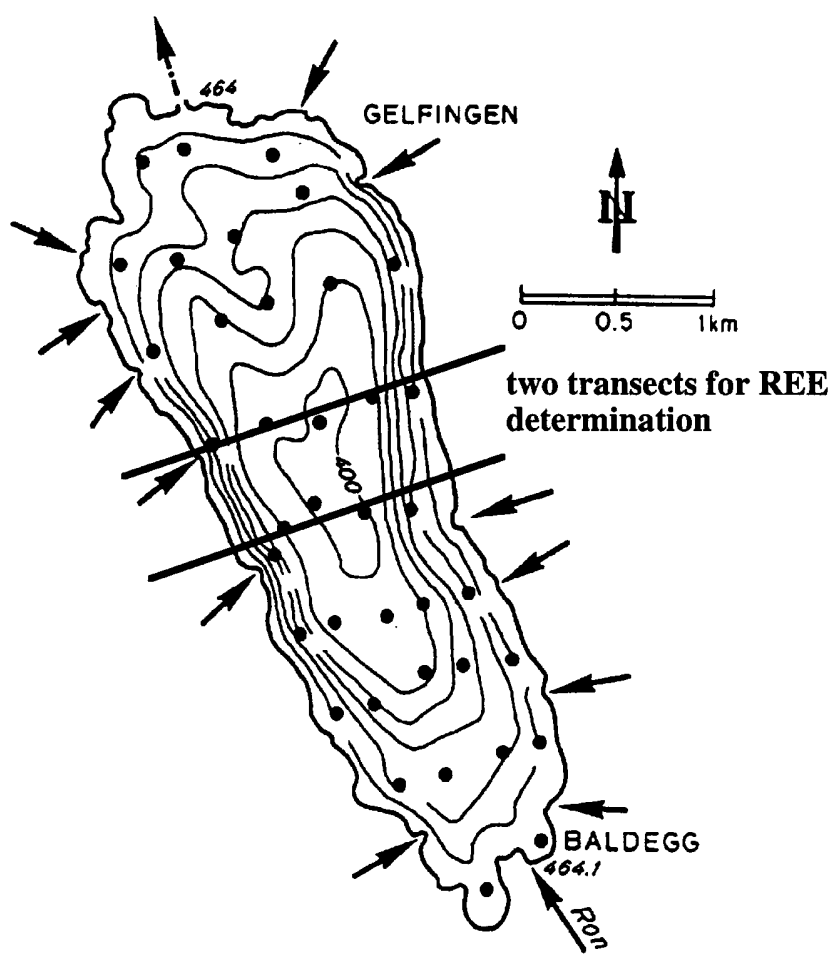

Figure 1. Position of cores taken in 1992 in Baldeggersee. The morphometry is given in intervals of $10 \mathrm{~m}$. Arrows indicate in- and outflows

\section{Sampling and analytical methods}

In October 1992 nine tansects with 2-6 short cores were sampled (Fig. 1). A total of 38 short cores was taken with a gravity corer of $6.3 \mathrm{~cm}$ diameter. The coring technique is described by Kelts et al. (1986). The cores were brought back to the laboratory and stored in their PVC-tubes at $4{ }^{\circ} \mathrm{C}$ in the dark. They were cut into two halves for stratigraphic analysis and sampling.

The stratigraphy of the 38 cores reflects the evolution of eutrophication and the change of oxygen conditions in the deep water (Fig. 2). Each core had three distinct sediment layers, which differed in color and composition:

1. Bottom secion: The bottom of all cores consisted of a light-grey, homogeneous marl. This section accumulated during a mesotrophic period of the lake. The absence of biogenic varves indicates bioturbation and an oxic sediment-water interface (Niessen and Sturm, 1987; Schaller and Wehrli, 1997).

2. Varved section: The biogenic varves show variable extension, depending on the water depth at which the individual core was taken. The well perserved biogenic varves originate from a period with seasonal or permanent benthic anoxia (Wehrli et al., 1997). 


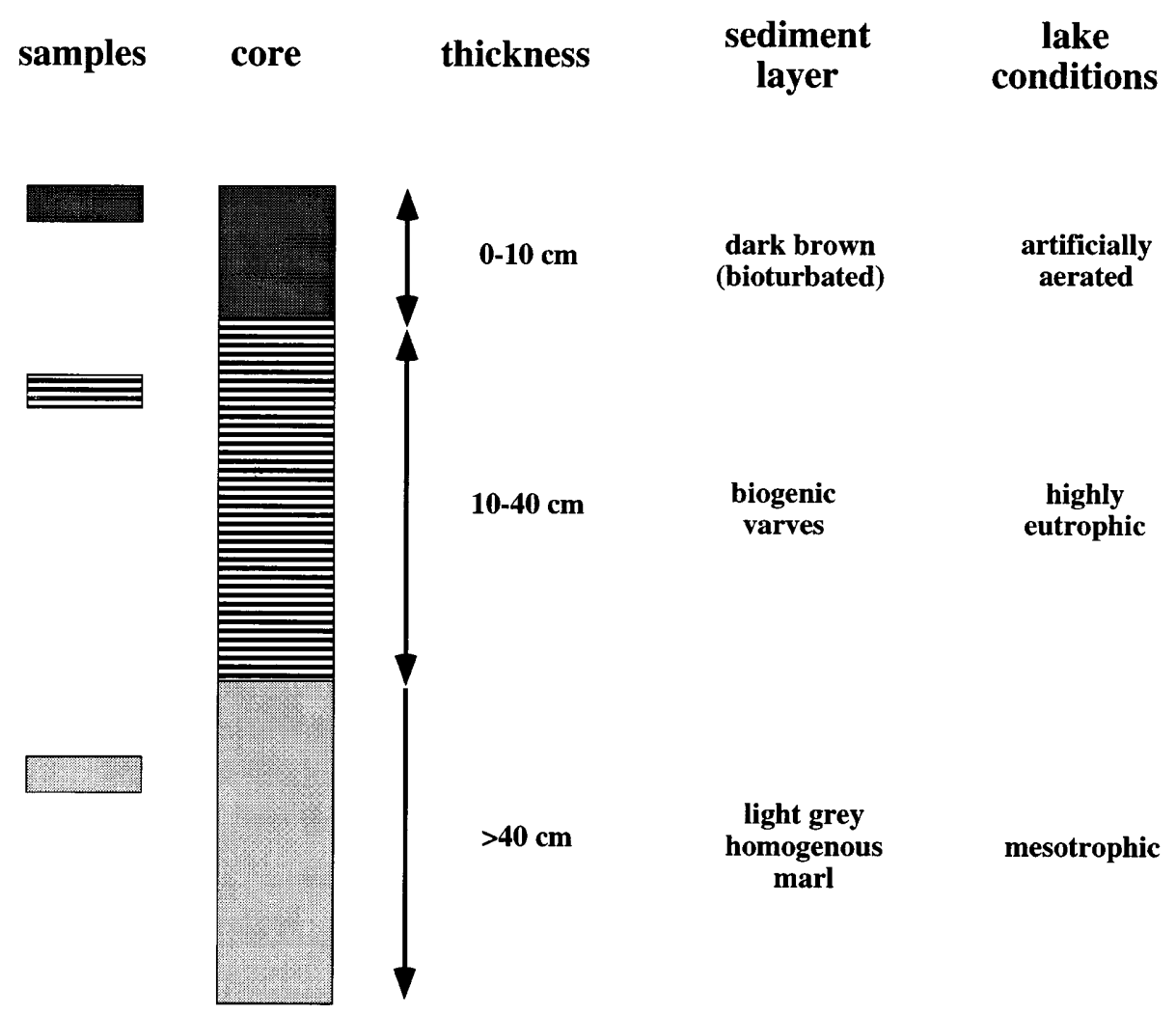

Figure 2. Sampling scheme for the sediment cores from Baldeggersee

3. Top section: The top of all cores, except those from the deep flat plain $(>55 \mathrm{~m}$ water depth), consists of a dark brown layer. This section is often homogenised due to bioturbation. The overlying water was oxic during deposition (Wehrli et al., 1997).

Subsections of $2 \mathrm{~cm}$ thickness were sampled in the three layers of all cores. Depending on the sedimentation rate (Lotter et al., 1997a) these subsections represent an average over 3,5 and 8 years for the dark brown, the varved and the light-grey layer, respectively. The samples of the varved and the light-grey section were always taken near the top of the respective layer, They represent similar oxygen conditions but often different times of deposition.

The samples were freeze dried with a Leybold Heraeus Lyvac GTZ and homogenised in an agate mortar. A portion of $50 \mathrm{mg}$ dry sediment was digested with $4 \mathrm{ml}$ $65 \%$ nitric acid (Merck suprapur) and $1 \mathrm{ml}$ of $30 \%$ hydrogen peroxide (Merck suprapur) in pressurised PTFE bombs in a Milestone "mls 1200 mega" microwave oven.

Fe and Mn concentrations were measured with a Flame-AAS (Perkin-Elmer AAS 2100). V, Cr, As and Mo concentrations were determined using an ICP-MS 
(ELAN 5000, Perkin Elmer Sciex). Precision, determined by replicate measurements of a subset of samples and internal standards was between $2 \%(\mathrm{Mn})$ and $5 \%$ $(\mathrm{Fe})$. Comparison with a rock standard (AIOL lake sediment) showed accuracy levels between 3\% (Mn) and $8 \%(\mathrm{~V})$. Parallel digestion of some samples with hydrofluoric acid showed that in the worst case (vanadium) more than $92 \%$ of the particulate fraction was dissolved by the digestion with nitric acid. The almost complete digestion with nitric acid is quite uncommon. It is due to the geological composition of the catchment. Marls, silt stones and limestone are dominant, while the siliceous fraction is of minor importance. For two transects (Fig. 1) concentrations of the lanthanide series (La to Hf) have been determined by ICP-MS.

Pore-water profiles were collected at two occasions using dialysis samplers. The method of pore-water collection is described by Urban et al., 1997. In November 1992 two Fe profiles were determined at a shallow $(25 \mathrm{~m})$ and a deep $(65 \mathrm{~m})$ station (Urban et al., 1997). In May another set of samples was collected at the deepest site and concentrations of $\mathrm{V}, \mathrm{Cr}$, As and Mo were determined by ICP-MS. The precision was $2 \%$ for $\mathrm{V}$ and As, $5 \%$ for Mo and $8 \%$ for $\mathrm{Cr}$.

The data were analysed with the software package "Transform" (Spyglass Inc.) using kriging interpolation functions. For each interpolation, except Mo (34) and $\mathrm{Cr}$ (36) all 38 samples were used. Range and number of samples per kriging pass were chosen in such a way, that at least 5 neighboring fixpoints were used do determine interpolated values. The variance was set to 1.0, the nugget to 0.0. Values at fixpoints were recalculated during interpolation and averaged. A comparison between calculated and measured values showed differences between $5-20 \%$. This accuracy is acceptable, because the interpolations are used only to outline general trends in the two dimensional distribution.

\section{Results}

Iron

In Table 1 average concentrations and standard deviations of the analysed metals are presented for each sediment section (Fig. 2). The highest average Fe concentration is found in the light-grey sediment layer deposited in the mesotrophic lake

Table 1. Average concentrations and standard deviations, calculated for $\mathrm{Fe}, \mathrm{V}, \mathrm{Cr}$, As and $\mathrm{Mo}$ in each sediment layer

\begin{tabular}{|c|c|c|c|c|}
\hline \multirow[t]{2}{*}{ element } & \multirow[t]{2}{*}{ units } & \multicolumn{3}{|c|}{ sediment layer } \\
\hline & & grey marl & biogenic varves & dark brown \\
\hline $\mathrm{Fe}$ & $\mathrm{mg} \mathrm{g}^{-1}$ & $15 \pm 3$ & $12 \pm 3$ & $10 \pm 3$ \\
\hline Mn & $\mathrm{mg} \mathrm{g}^{-1}$ & $0.4 \pm 0.1$ & $0.3 \pm 0.1$ & $0.3 \pm 0.3$ \\
\hline V & ppm & $25 \pm 7$ & $22 \pm 4$ & $22 \pm 5$ \\
\hline $\mathrm{Cr}$ & ppm & $25 \pm 7$ & $24 \pm 4$ & $22 \pm 5$ \\
\hline As & ppm & $6 \pm 1$ & $6 \pm 1$ & $5 \pm 1$ \\
\hline M0 & ppm & $0.8 \pm 0.3$ & $1.0 \pm 0.3$ & $0.9 \pm 0.3$ \\
\hline
\end{tabular}


Table 2. Analysis of variance. Average concenrations determined in each layer were pairwisely tested for the null-hypothesis (No statistical evidence for different mean values). Numbers given show cases where the test value was significantly higher than the critical value $(c=1.70$, Kreyszig, 1975) Confidence level $95 \%$

\begin{tabular}{llll}
\hline & $\begin{array}{l}\text { light grey vs. } \\
\text { dark brown }\end{array}$ & $\begin{array}{l}\text { light grey vs. } \\
\text { varved section }\end{array}$ & $\begin{array}{l}\text { varved section vs. } \\
\text { dark brown }\end{array}$ \\
\hline $\mathrm{Fe}$ & 5.5 & 4.1 & - \\
$\mathrm{V}$ & 1.8 & 2.0 & - \\
$\mathrm{Cr}$ & 4.6 & 3.9 & - \\
$\mathrm{As}$ & 5.7 & - & 2.9 \\
$\mathrm{Mo}$ & - & 3.0 & 4.0 \\
\hline
\end{tabular}

$\left(15 \pm 3 \mathrm{mg} \mathrm{g}^{-1}\right)$. The dark brown layer from the top of the cores contains the lowest Fe concentration $\left(10 \pm 3 \mathrm{mg} \mathrm{g}^{-1}\right)$. A pairwise comparison of average values ( $\mathrm{t}$-test on a $95 \%$ confidence level, Table 2) indicates that the average value of $\mathrm{Fe}$ in the lightgrey marl is significantly different from the those of the varved and the dark brown layer.

The analysis of the three sediment sections of all cores is summarised in Figure 3. The different plots display varitions in space and benthic oxygen conditons: the individual scatter plots show concentration changes with depth. Three plots in row represent changes in benthic redox conditons during deposition of the layers. The first graph in a row contains data of the light-grey sediment from the mesotrophic lake before 1885, the central plot displays concentrations in the varved sediment from the decades between 1960 and 1980 and the figure at the right shows the actual situation in the artificially oxygenated lake.

The whole dataset is shown in Figure $3 \mathrm{a}-\mathrm{c}$ in the form of scatter plots. The large variability of Fe concentrations at the littoral stations can be attributed to the allochthonous input. In the zone below $13 \mathrm{~m}$ iron concentrations are focused towards the deepest site since the lake has been eutrophic (varved and dark brown core section). However, only the dark brown section shows a statistically relevant correlation between iron concentrations and water depth (Table 3).

The horizontal distributions of Fe concentrations are presented in Figure 3d-f. In the light-grey sediment layer, iron is more or less randomly distributed. In the varved section the distribution indicates a focusing effect: Iron concentrations increase towards the deep, central basin. Low concentrations are found in the shallower regions. This iron focusing is more pronounced in the dark brown layer.

The general trends are outlined in Figures $3 g-i$, where average concentrations and standard deviations are plotted for three different water-depth ranges. Following the morphological description of Niessen and Sturm (1987) the sediment cores were divided into four categories: (1) The depth range $0-13 \mathrm{~m}$ is influenced to a great extend by the different inflows (Fig. 1), i.e. the allochthonous fraction determines the metal concentration. This range has been omitted in Figures $3 \mathrm{~g}-\mathrm{i}$. (2) The zone of $13-33 \mathrm{~m}$ includes two plains with only moderate inclines at the northern and southern end of the lake. (3) The range $33-53 \mathrm{~m}$ is characterised by steep slopes. (4) The profundal between 53 and $67 \mathrm{~m}$ consists of a wide plain. The results 


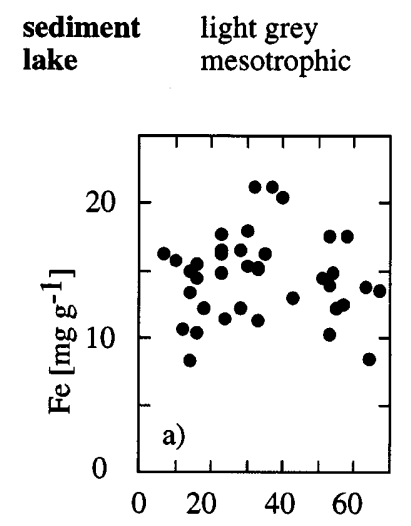

biogenic varves

dark brown

highly eutrophic

aerated
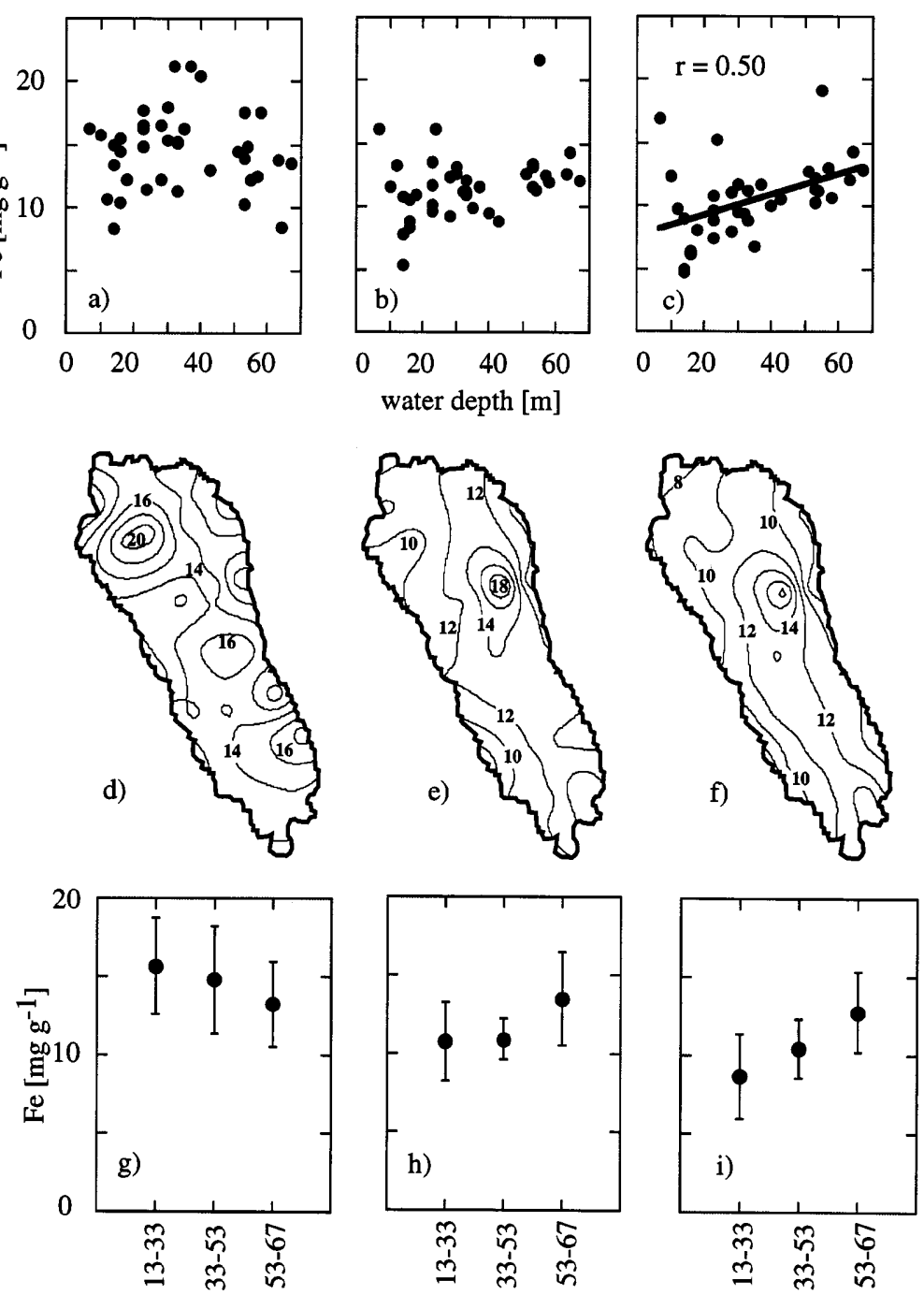

water-depth range $[\mathrm{m}]$

Figure 3. (a, b, c) Iron concentrations plotted against water depth of the cores. (d, e, f) Horizontal distribution of iron concentrations $\left[\mathrm{mg} \mathrm{g}^{-1}\right]$ in the sediment of Baldeggersee. The graphs represent a krigin interpolation of samples from three sediment horizons which correspond to mesotrophic (d), eutropic (e) and artificially aerated (f) lake conditions. (g, h, i) Average concentrations of Fe for differnt water-depth ranges 
Table 3. Correlation matrices. The calculation is based on the 38 samples of each sediment layer. The presented submatrices are parts of the global matrices (14 parameters) for each layer. Only correlations significant on the $95 \%$ level are shown

\begin{tabular}{|c|c|c|c|c|c|c|c|}
\hline \multicolumn{8}{|c|}{ light grey marl } \\
\hline & depth & $\mathrm{Fe}$ & $\mathrm{Mn}$ & $\mathrm{V}$ & $\mathrm{Cr}$ & As & Mo \\
\hline depth & - & & & & & & \\
\hline $\mathrm{Fe}$ & - & - & & & & & \\
\hline Mn & - & 0.56 & - & & & & \\
\hline $\mathrm{V}$ & - & - & - & - & & & \\
\hline $\mathrm{Cr}$ & - & - & - & 0.96 & - & & \\
\hline As & - & - & - & 0.86 & 0.85 & - & \\
\hline Mo & - & - & - & - & - & - & - \\
\hline \multicolumn{8}{|c|}{ varved layer } \\
\hline & depth & $\mathrm{Fe}$ & $\mathrm{Mn}$ & $\mathrm{V}$ & $\mathrm{Cr}$ & As & Mo \\
\hline depth & - & & & & & & \\
\hline $\mathrm{Fe}$ & - & - & & & & & \\
\hline $\mathrm{Mn}$ & 0.66 & - & - & & & & \\
\hline $\mathrm{V}$ & - & 0.68 & - & - & & & \\
\hline $\mathrm{Cr}$ & - & 0.74 & - & 0.76 & - & & \\
\hline As & 0.55 & 0.69 & 0.53 & 0.59 & _- & - & \\
\hline Mo & 0.57 & - & 0.83 & - & - & - & - \\
\hline \multicolumn{8}{|c|}{ dark brown layer } \\
\hline & depth & $\mathrm{Fe}$ & $\mathrm{Mn}$ & $\mathrm{V}$ & $\mathrm{Cr}$ & As & Mo \\
\hline depth & - & & & & & & \\
\hline $\mathrm{Fe}$ & 0.50 & - & & & & & \\
\hline Mn & 0.59 & - & - & & & & \\
\hline $\mathrm{V}$ & 0.57 & 0.86 & - & & - & & \\
\hline $\mathrm{Cr}$ & - & 0.76 & - & 0.73 & - & & \\
\hline As & 0.62 & 0.91 & 0.58 & 0.89 & 0.57 & - & \\
\hline Mo & 0.52 & - & - & - & - & - & - \\
\hline
\end{tabular}

of Figure $3 g-i$ suggest that for the three layers average Fe concentrations vary only in the depth range $13-53 \mathrm{~m}$. The relative decrease of average Fe concentration between the light-grey and the dark brown section is $45 \%(13-33 \mathrm{~m})$ and $31 \%$ $(33-53 \%)$. However, concentrations in the deepest part $(53-67 \mathrm{~m})$ remained nearly constant. The average of $13.2 \pm 2.7 \mathrm{mg} \mathrm{g}^{-1}$ in the light grey layer at the bottom of the cores is comparable to $12.7 \pm 2.6 \mathrm{mg} \mathrm{g}^{-1}$ in the dark brown layer at the sediment surface.

In Figure 4 iron concentrations are plotted against La concentrations for the two transects in the center of the lake which are displayed in Figure 1. In the case of Baldeggersee, lanthanum can be used as tracer for the allochthonous metal input (Schaller et al., 1997). A significant correlation of iron with lanthanum is only found in the light-grey layer. In this core section the Fe concentrations appear to be 


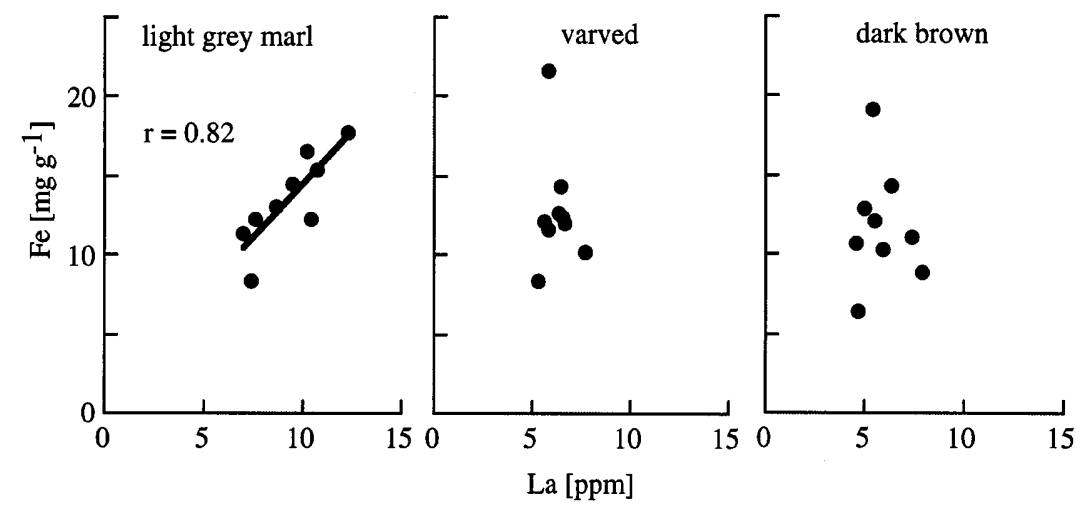

Figure 4. Iron concentrations $\left[\mathrm{mg} \mathrm{g}^{-1}\right]$ plotted against La concentrations ppm for nine cores of the transects shown in Figure 1

controlled by allochthonous input. In the two layers deposited under eutrophic lake conditions no correlation can be observed.

\section{Vanadium, Chromium, Arsenic and Molybdenum}

\section{Sedimentary concentrations}

The comparison of the average concentrations of the three sediment layers (Table 1) shows that $\mathrm{V}, \mathrm{Cr}$ and As follow the same general trend as Fe. The highest values are found in the light-grey layer (V: $25 \pm 7 \mathrm{ppm}, \mathrm{Cr}: 28 \pm 6 \mathrm{ppm}, \mathrm{As}: 6 \pm 1 \mathrm{ppm})$ and the lowest values are found in the dark brown layer (V: $22 \pm 5$ ppm, Cr: $22 \pm 5$ ppm, As: $5 \pm 1 \mathrm{ppm})$. Table 2 shows that both $\mathrm{Cr}$ and $\mathrm{V}$ are significantly enriched in the grey layer, As is depleted in the recent brown layer and Mo is enriched in the varved section deposited under anoxic conditions.

Vanadium was chosen to illustrate the behavior of the trace metals. Figure 5 depicts the similar variations of $\mathrm{V}$ concentrations in space and benthic oxygen conditions as Figure 3 for iron. Figures $5 \mathrm{a}-\mathrm{c}$ show $\mathrm{V}$ concentrations plotted against water depth for all 38 samples in the three layers. A correlation of concentration with depth is found only in the top section of the sediment, which has been deposited in an artificially oxygenated hypolimnion (Table 3). The horizontal distribution patterns (Fig. $5 \mathrm{~d}-\mathrm{f}$ ) of $\mathrm{V}$ in the dark brown sediment layers again indicate early diagenetic redistribution processes, i.e. increase of $\mathrm{V}$ concentrations with water depth.

Figures $5 \mathrm{~g}-\mathrm{i}$ compare the average concentrations at three different water depth ranges in the three sediment strata. Again, data from littoral zones above $13 \mathrm{~m}$ depth have been excluded from the analysis. Similar to iron a clear trend of vanadium concentrations with water depth is observed only in the top sections of the sediment cores. Comnpared to the older strata of the grey layer, the top section shows a relative depletion in the depth range of $13-33 \mathrm{~m} \mathrm{(24 \% )}$ and an enrichment of $\mathrm{V}(15 \%)$ in the deep central basin $(53-67 \mathrm{~m})$ of the lake. 


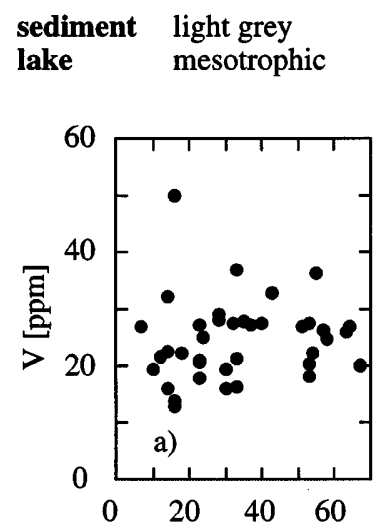

biogenic varves

dark brown

highly eutrophic

aerated
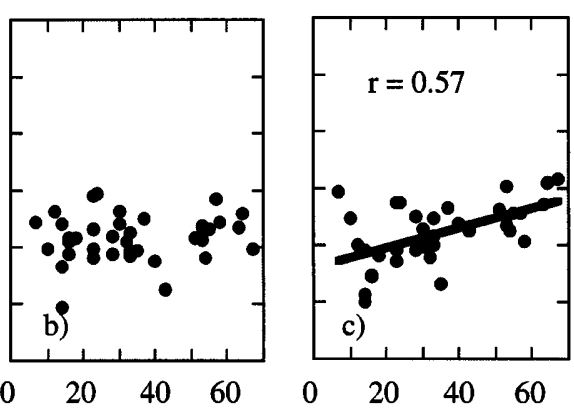

water depth [m]
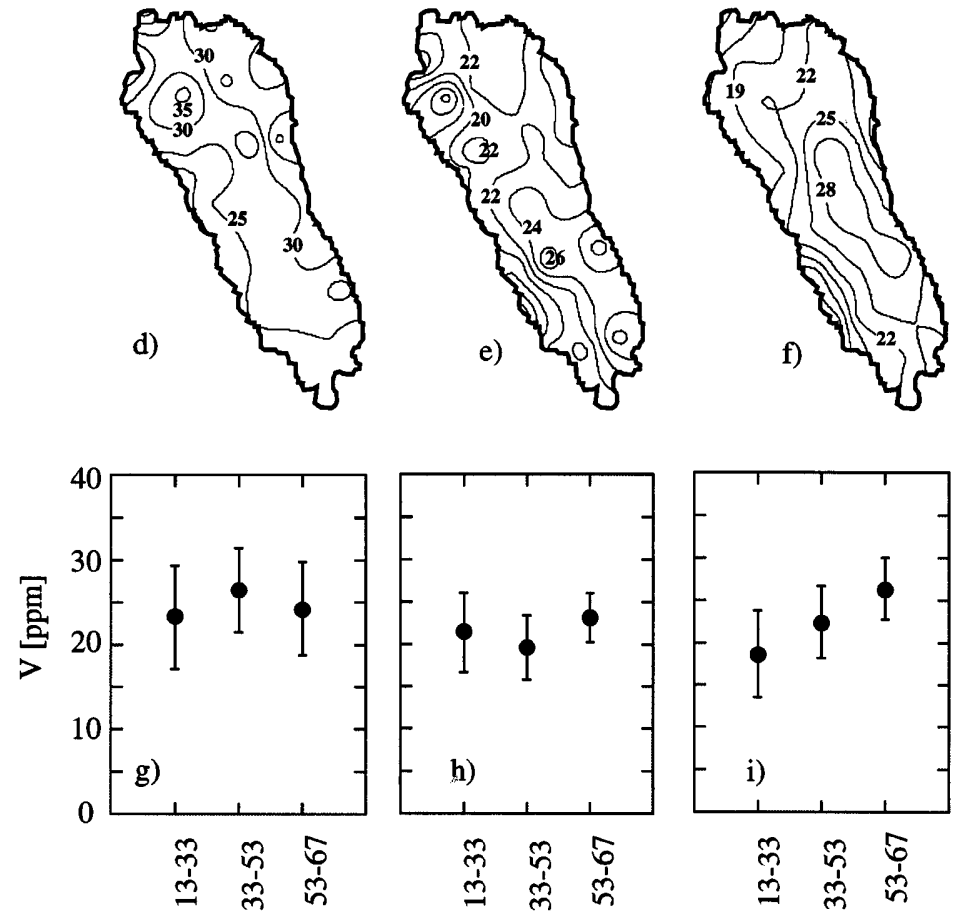

water-depth range $[\mathrm{m}]$

Figure 5. (a, b, c) Vanadium concentrations plotted against water depth of the cores. (d, e, f) Horizontal distribution of vanadium concentrations $\left[\mathrm{mg} \mathrm{g}^{-1}\right]$ in the sediment of Baldeggersee. The graphs represent a krigin interpolation of samples from three sediment horizons which correspond to mesotrophic (d), eutropic (e) and artificially aerated (f) lake conditions. (g, h, i) Average concentrations of $\mathrm{V}$ for differnt water-depth ranges 
For the other metals only the average data for different depth ranges are given in Figure 6 in order to compare the general trends. Average Cr concentrations decreased during eutrophication (Fig. 6a-c, Table 2). However, in contrast to $\mathrm{V}$ there is no significant correlation with water depth in the most recent sediments (Table 3). The As values (Fig. 6d-f) show a different picture than V or Cr. For all three layers As concentrations are highest in sediments from the deepest part of the lake (53 and $67 \mathrm{~m}$ ) and lowest between 13 and $33 \mathrm{~m}$. No difference in average As concentrations is observed when the lake changes from mesotrophic to eutrophic (Table 1 and 2). The average value of arsenic in the dark brown layer however, is lower. A significant correlation with water depth is observed in the varved and the dark brown section. The average concentrations of Mo indicate a major increase of Mo in the varved layer (Table 1 and 2). Figure $6 \mathrm{~g}-\mathrm{i}$ and Table 3

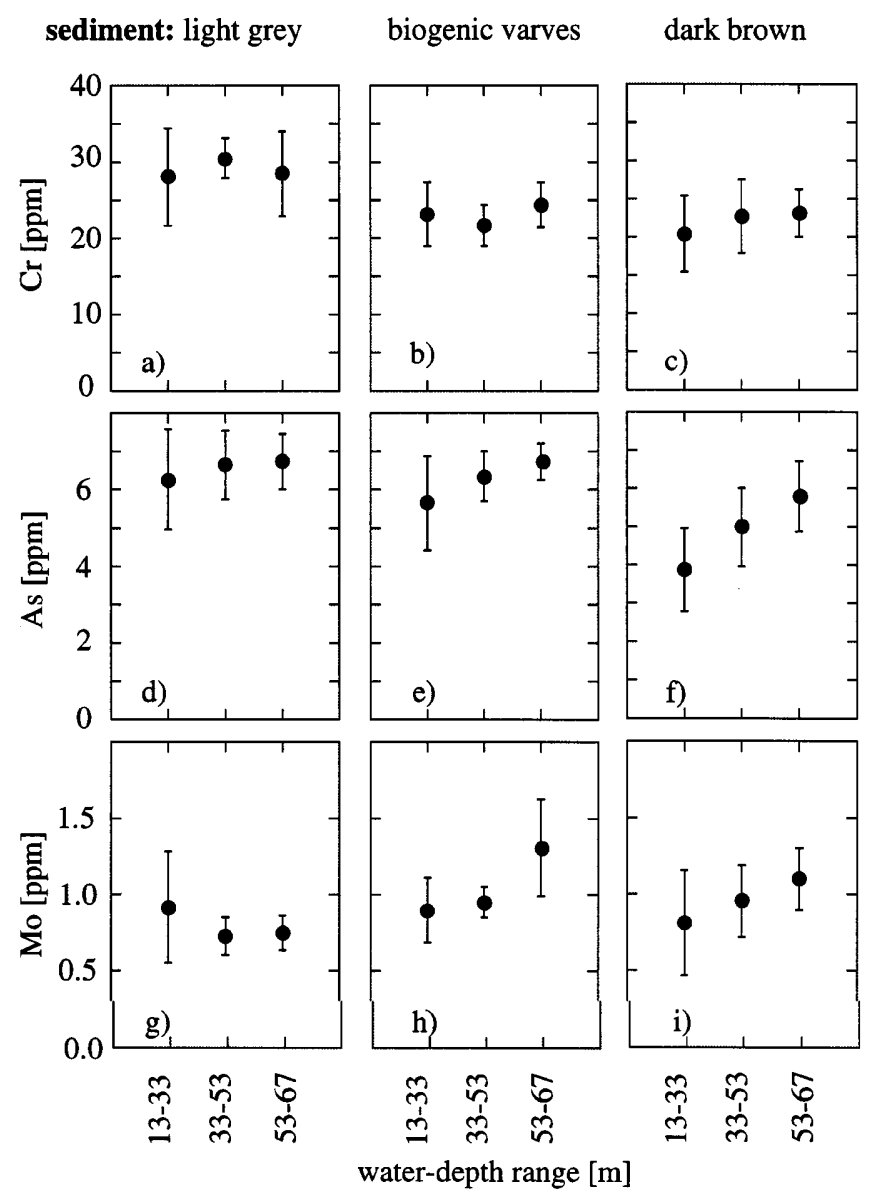

Figure 6. Average concentrations, calculated for different water-depth ranges: (a, b, c) $\mathrm{Cr}$ [ppm], $(\mathrm{d}, \mathrm{e}, \mathrm{f})$ As $[\mathrm{ppm}],(\mathrm{g}, \mathrm{h}, \mathrm{i})$ Mo $[\mathrm{ppm}]$ 
reveal increasing concentrations with water depth in the varved and the dark brown layer.

Pore-water profiles

Figure 7 presents pore-water profiles of $\mathrm{Fe}, \mathrm{V}, \mathrm{Cr}$, As and Mo. The Fe samples were collected in November 1992 (Urban et al., 1997). Both profiles show an increase of dissolved Fe concentrations through the diffusive boundary layer and a second gradient within the sediment. The profile from the deep station $(65 \mathrm{~m})$ shows a concentration maximum near the sediment-water interface. This indicates intense reductive dissolution to act as a source for $\mathrm{Fe}^{2+}$ in the pore water. Urban et al. (1997) calculated the flux of Fe at the pelagic station $\left(0.15 \mathrm{mmol} \mathrm{m}^{-2} \mathrm{~d}^{-1}\right)$ to be significantly higher than at the litoral station $\left(0.06 \mathrm{mmol} \mathrm{m}^{-2} \mathrm{~d}^{-1}\right)$. They observed a similar increase of diffusive fluxes with water depth in Sempachersee, $30 \mathrm{~km}$ West of Baldeggersee.

At a sediment depth of ca. $5-8 \mathrm{~cm}$ the Fe profile from the pelagic station indicates elimination of dissolved Fe from the pore water. Two sources produce a flux of dissolved Fe to this depth range: (1) the concentration maximum near the sediment-water interface and (2) an additional source deeper in the sediment (Schaller et al., 1997). The calculated fluxes of 0.23 and $0.062 \mu \mathrm{Mol} \mathrm{m}^{-2} \mathrm{~d}^{-1}$ at the interface and from below, respectively, correspond to $40 \%$ of the average Fe accumulation rate (Walser, unpublished results).

Vanadium, arsenic and molybdenum show all a clear peak near the sedimentwater interface. On the other hand, dissolved $\mathrm{Cr}$ concentrations increase linearly through the interface. In the case of V, As and Mo calculated pore-water fluxes are

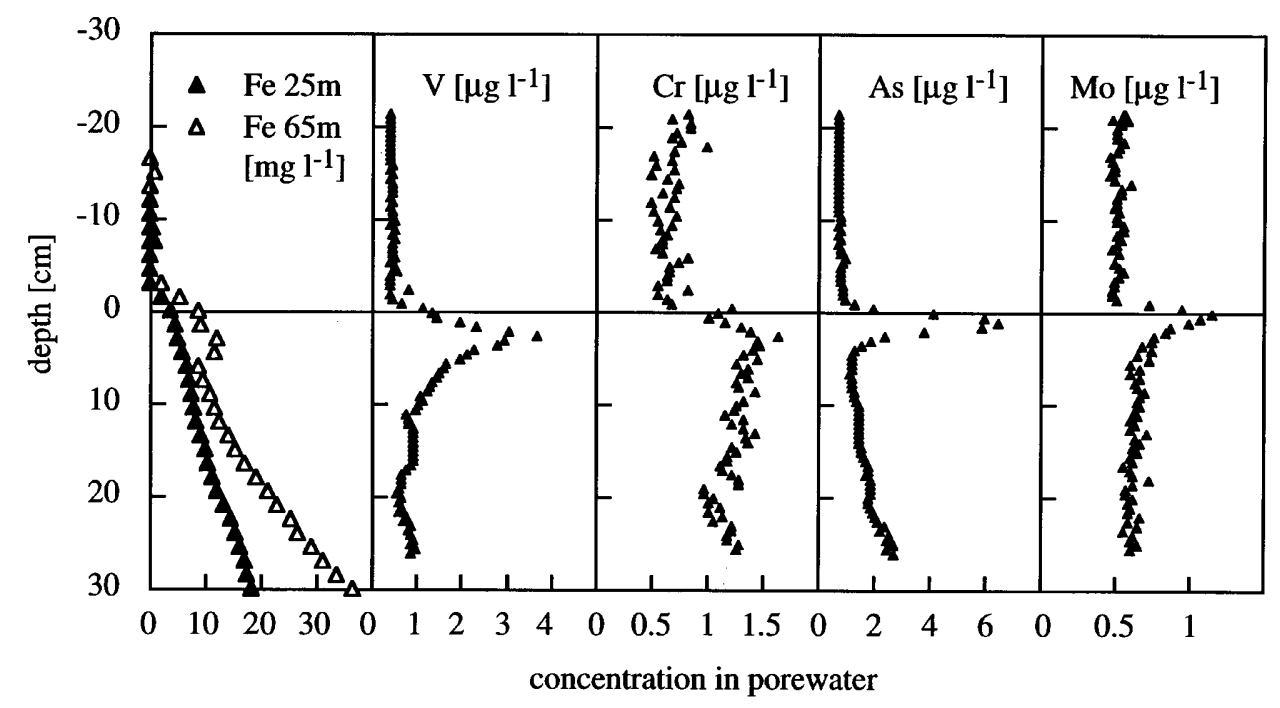

Figure 7. Pore-water profiles for Fe from November 1992 and of V, Cr, As and Mo from May 1994 
similar in magnitude as the sediment accumulation rate. For $\mathrm{Cr}$ the accumulation rate is about two orders of magnitude higher than the pore-water flux (Walser, unpublished results).

\section{Correlation matrix}

Table 3 presents the results of calculated correlation matrices for all measured elements in each layer. Only coefficients are shown which are significant on a $95 \%$ level (Kreyszig, 1975). In addition to the correlation with water depth, two correlation patterns can be observed:

1. The concentrations of the trace metals $\mathrm{V}, \mathrm{Cr}, \mathrm{As}$ in the varved and dark brown sections correlate with Fe. No such relationship is observed in the grey marl deposited in the mesotrophic lake.

2. Manganese correlates with Mo and As in the varved section and the dark brown layer.

\section{Discussion}

\section{The iron cycle}

The important role of iron for the scavenging of trace metals in lakes and oceans is well documented in the literature. The iron cycle in lakes has recently been thoroughly reviewed by Davison (1993) and de Vitre et al. (1994). Metal transport by Fe particles in lakes has been investigated by Sigg et al. (1987) and Tessier (1992). Fe oxyhydroxides (Hamilton-Taylor and Davison, 1995), Fe sulfides (Huerta-Diaz and Morse, 1992), Fe carbonates and phosphates (Emerson, 1976; Friedl et al., 1996) may control trace-metal concentrations in pore waters.

Our results suggest that the iron cycle in Baldeggersee changed dramatically in the course of eutrophication and increasing anoxia. Different lines of evidence support the hypothesis that internal redox cycling was negligible in the mesotrophic lake with its oxic hypolimnion. Iron concentrations in the marl sections of the sediments are larger in shallower zones above $40 \mathrm{~m}$ (Fig. 3a, $\mathrm{d}$ and g). Deposition of coarse-grained soil particles from the catchment is more important in this depth range. The variability of iron concentrations deposited in the sediments of the mesotrophic lake correlates strongly with geochemical indicators for allochthonous input such as La (Fig. 4a). On the other hand, no correlation is observed with trace metals that adsorb strongly to autochthonous Fe particles (Table 3).

In the course of eutrophication several geochemical signals preserved in the varved sections of the sediment point towards an intensified remobilisation of Fe. Average iron concentrations decreased by $20 \%$ (Table 1 ) when the grey marls are compared with the varved sections. Interpreting this decrease of average concentrations in terms of net $\mathrm{Fe}$ accumulations by taking into account an average sedimentation rate of $1050 \mathrm{~g} \mathrm{~m}^{-2} \mathrm{a}^{-1}$ (Lotter et al., 1997) and a total sediment area of $5.22 \cdot 10^{6} \mathrm{~m}^{2}$ the accumulation rates would be $84 \mathrm{t} \mathrm{Fe} \mathrm{a}^{-1}$ and $66 \mathrm{t} \mathrm{Fe} \mathrm{a}^{-1}$ for the lightgrey and the varved layer, respectively. Assuming constant Fe input the increased 
reductive mobilisation would result in a net los of $18 \mathrm{t} \mathrm{Fe}^{-1}$ through the outflow. The hypothesis of iron remobilisation from shallower zones via the outflow is supported by additional observations. Horizontal distribution patterns show a depletion of Fe concentration only in the shallower parts $(13-33 \mathrm{~m}$ and $33-53 \mathrm{~m}$; Fig. $3 \mathrm{~h}$, i). On the other hand, the iron concentrations in deepest part of the lake $(53-67 \mathrm{~m})$ are constant in all three sediment layers (Fig. 3g-i).

Since concentrations instead of fluxes have been compared in Fig. 3 possible dilution effects have to be discussed. We have tested whether the $\mathrm{CaCO}_{3}$ content of the samples could explain correlation between Fe concentrations and water depth. However, a correlation of $\mathrm{Fe}$ against the inverse $\mathrm{Ca}$ concentration was statistically not significant (varved layer: $\mathrm{r}^{2}=0.14$, dark brown layer $\mathrm{r}^{2}=0.22$ ). We therefore conclude that changes in the internal Fe cycle are the most probable mechanisms to explain the trends in Figure 3.

For Baldeggersee and Zugersee the authors have already discussed effects of changing redox conditions in the deep-water on the horizontal distribution of manganese (Schaller and Wehrli, 1997). It has been shown that manganese accumulates in the deepest part of the lake. This geochemical-focusing effect is most intense in situations where an anoxic sediment is in contact with an oxic water column. In this case $\mathrm{Mn}^{2+}$ diffuses out of the sediment and is horizontally transported during the slow oxidation by $\mathrm{O}_{2}$. Characteristic horizontal mixing lengths of $60-200 \mathrm{~m}$ were obtained from calculations based on a half life of about 1 day for $\mathrm{Mn}(\mathrm{II})$ in oxic water (Schaller and Wehrli, 1997). A similar calculation is presented here for Fe(II) which has a shorter half life. At $\mathrm{pH}=7-7.5 \mathrm{Fe}$ (II) is oxidised with $0.5<\mathrm{t}_{1 / 2}<5$ hours (Davison and De Vitre, 1992; Davison, 1993). The characteristic length scale $\mathrm{L}_{\mathrm{i}}$ can be estimated by $\mathrm{L}_{\mathrm{i}}=\left(\mathrm{K}_{\mathrm{i}} \cdot \tau_{\mathrm{c}}\right)^{0.5}$, where $\mathrm{K}_{\mathrm{i}}$ denotes a turbulent diffusion coefficient and $\tau_{c}$ is the characteristic time for oxidation (Schaller and Wehrli, 1997). The turbulent diffusion coefficients for vertical and horizontal mass transport in lakes are approximately $\mathrm{K}_{\mathrm{v}} \leq 10^{-6} \mathrm{~m}^{2} \mathrm{~s}^{-1}$ and $\mathrm{K}_{\mathrm{h}}=0.02-0.3 \mathrm{~m}^{2} \mathrm{~s}^{-1}$, respectively (Peeters et al., 1996; Wüest et al., 1996). The characteristic time $\tau_{\mathrm{c}}=\ln 2 \cdot \mathrm{t}_{1 / 2}$, assuming that the elimination of $\mathrm{Fe}$ from the water column by oxidation and subsequent reprecipitation can be described by a pseudo first order reaction (Rudnicki and Elderfield, 1993 ) with rate constant $\mathrm{k}$ and $\tau_{\mathrm{c}}=1 / \mathrm{k}$. Horizontal and vertical mixing length are then in the order of $\mathrm{L}_{\mathrm{H}}=5-60 \mathrm{~m}$ and $\mathrm{L}_{\mathrm{V}}=0.1 \mathrm{~m}$ respectively. A comparison between the two length scales indicates tht dissolved $\mathrm{Fe}^{2+}$ released from the sediments will be mixed horizontally but not vertically during the oxidation process.

The reaction products of $\mathrm{Fe}(\mathrm{II})$ oxidation consist of small colloidal $\mathrm{Fe}$ (III) particles with very small settling velocities (De Vitre et al., 1994; Sigg, 1994). The formation of colloids is slow compared to oxidation. The elimination of Fe from the water column may be rather controlled by the slow coagulation step followed by settling of aggregates (De Vitre et al., 1994). The elimination by coagulation has been described by a first-order rate law with $\mathrm{k}=0.033 \mathrm{~h}^{-1}$ (De Vitre et al., 1994). If we take the formation of colloidal particles as the characteristic timescale we obtain horizontal transport distances of 50-180 m. Therefore, Fe diffuse out of the sediments is transported towards the water column in the center of the lake, where two processes can occur. At shallow water depths advective mixing may transport small colloids towards the outflow, at greater water depths aggregation and settling will dominate. This last process leads to a redeposition of iron towards the central basin 
(geochemical focusing). Internal cycling of Fe plays an essential role for the labile trace-element fraction in the water column. Freshly precipitated iron hydroxides consist of small particles $(<1 \mu \mathrm{m})$ with large surface area (Sigg, 1994). Oxoanions of $\mathrm{V}, \mathrm{Cr}$ and As strongly sorb to hydrous ferric oxides (Dzombak and Morel, 1990). The positive correlation of Fe with V, Cr and As (Table 3) supports a redeposition mechanism.

In the samples of the dark brown section a strong Mn enrichment was observed, which was attributed to a geochemical-focusing effect (Schaller and Wehrli, 1997). Surprisingly, no significant iron enrichment is found in these samples (Fig. 3). This difference between manganese and iron might be caused by the tendency of Fe to form small colloidal particles with low settling velocities. Thus fine Fe particles might be preferentially lost through the outflow. However, the particle dynamics of colloidal Fe oxides in lakes warrants further study.

\section{Vanadium, Chromium and Arsenic}

Equilibrium calculations predict that the three metals are present as oxyanions in oxic waters of neutral $\mathrm{pH}\left(\mathrm{H}_{2} \mathrm{VO}_{4}^{-} / \mathrm{HVO}_{4}^{2-}, \mathrm{HCrO}_{4}^{-} / \mathrm{CrO}_{4}^{2-}, \mathrm{H}_{2} \mathrm{AsO}_{4}^{-} / \mathrm{HAsO}_{4}^{2-}\right.$, Turner et al., 1981). Under reducing conditions cationic species of vanadyl (IV), vanadium (III) and chromium (III) prevail (Wehrli and Stumm, 1989; Wanty and Goldhaber, 1992; Richard and Bourg, 1991). Arsenic (III) in contrast, forms oxyanions (Cullen and Reimer, 1989). Both, the reduced as well as the oxidised species of $\mathrm{V}, \mathrm{Cr}$ and As strongly adsorb to oxide surfaces (Dzombak and Morel, 1990).

The grey homogenous marl deposited in the mesotrophic lake shows clear signs of bioturbation (Niessen and Sturm, 1987). This indicates that oxygen penetrated into the sediment. The enrichment of $\mathrm{V}$ and $\mathrm{Cr}$ in this layer compared to the more recent sections may be interpreted by a trapping mechamism. Iron and manganese oxides present at the oxic sediment-water interface may effectively trap V, Cr and As diffusing towards the sediment surface. Postdepositional mobility is very low under these conditions (Shaw et al., 1990; Thomson et al., 1993). This explains the lack of correlation between iron and the trace metals V, Cr and As in samples from the grey marl (Table 3). The fact that As shows also rather high concentrations in the varved section, where $\mathrm{V}$ and $\mathrm{Cr}$ are low points towards an additional sink in presence of sulfide such as $\mathrm{As}_{2} \mathrm{~S}_{3}$ or solid-solutions with iron sulfides (Aggett and Brien, 1985; Seyler and Martin, 1989).

In the eutrophic lake represented by the varved section and the brown layer carrier phases of $\mathrm{V}, \mathrm{Cr}$ and As are reductively dissolved at the anoxic sedimentwater interface. The resulting pore-water gradient (Fig. 7) drives diffusion of dissolved $\mathrm{V}, \mathrm{Cr}$ and As from the sediment to the water column. This may explain the general decrease of average concentrations in the varved and the dark brown layer. The strong correlation between these trace metals and Fe indicates a control of the sedimentation rates by $\mathrm{Fe}$ phases. Freshly formed $\mathrm{Fe}$ oxyhydroxides near the vicinity of the redox-gradient promote adsorption and scavenging of dissolved $\mathrm{V}, \mathrm{Cr}$ and As. A coupling of the cycles of $\mathrm{V}$ and As with the Fe cycle can explain the increase of concentrations with water-depth for these two metals in the dark brown layer (artificially aerated lake conditions). 


\section{Molybdenum}

In oxic lake waters Mo is present as $\mathrm{MoO}_{4}^{2-}$ (Baes and Mesmer, 1976). Under reducing conditions the stable oxidation state is $\mathrm{Mo}(\mathrm{IV})$. In the presence of free sulfide, dissolved Mo is controlled by $\mathrm{MoS}_{2}$ (Emerson and Huested, 1991).

Average concentrations indicate an enrichment of molybdenum in the varved layer (Table 1 and 2). During the deposition of this layer, anoxic conditions prevailed in the deep water of Baldeggersee. Mo is enriched in marine sediments overlaid by a anoxic water column (Emerson and Huested, 1991) due to a scavenging by $\mathrm{MoS}_{2}$. However, the sulfide concentration of the water column of most lakes is too low to allow for a precipitation of pure Mo-sulfide phases. Magyar et al. (1993) postulated three processes for the elimination of Mo from the water column of the seasonally anoxic Greifensee: (1) coprecipitation of $\mathrm{Mo}(\mathrm{VI})$ in mixed $\mathrm{FeS} \cdot \mathrm{MoS}_{3}$ phases, (2) coprecipitation with Mn oxides and (3) diffusive transport of dissolved Mo(VI) into the sediment. Two of these mechanisms can contribute to the Mo enrichment in the varved layer. Free sulfide was present in the meromictic hypolimnion. Precipitation of FeS in the water column was possible. In addition oxidation of dissolved $\mathrm{Mn}$ (II) at the redox gradient could promote the adsorption of Mo onto the freshly formed oxide surfaces (Berang and Grill, 1974; Pilipchuk and Volkov, 1974; Sugawara, 1961). However, the porewater profiles in Figure 7 suggest that diffusive transport of Mo from the water column can be neglected.

\section{Conclusions}

We have analysed the distribution patterns and the average concentrations of $\mathrm{Fe}, \mathrm{V}$, $\mathrm{Cr}$, As and Mo in three different sediment strata of Baldeggersee. The following observations provide useful constraints for the reconstruction of redox conditions in the hypolimnion.

1) Sediments deposited under oxic conditions are characterised by high concentrations of $\mathrm{Fe}, \mathrm{V}$ and $\mathrm{Cr}$ and a strong correlation between $\mathrm{Fe}$ and tracers for allochthonous input such as La. The lack of an internal iron cycle minimises losses and the redistribution of $\mathrm{Fe}, \mathrm{V}$ and $\mathrm{Cr}$.

2) The varved sections were deposited in an anoxic benthic environment. The most prominent feature of these samples is the enrichment of Mo. An intense Mn cycle and the presence of free sulfide in the water column increase the retention of this metal in the sediment. On the other hand, a depletion of $\mathrm{Fe}, \mathrm{V}$ and $\mathrm{Cr}$ and the correlation of $\mathrm{V}, \mathrm{Cr}$ and $\mathrm{As}$ with $\mathrm{Fe}$ indicate that an intense iron cycle was active during deposition. Export in the form of colloidal Fe hydroxides acted as an additional sink for $\mathrm{Fe}, \mathrm{V}$ and $\mathrm{Cr}$.

3) The most recent sediment section was deposited in the artificially oxygenated lake. In contrast to manganese (Schaller and Wehrli, 1997) geochemical focusing of Fe does not lead to a significant increase of concentrations. Depletion of V and As in the littoral zone again indicates enhanced export of Fe colloids through the outflow.

Analysis of several cores is required to assess the postdepositional mobility of redoxactive metals. The distributions of $\mathrm{Fe}, \mathrm{V}$ and $\mathrm{Cr}$ are useful indicators for the 
presence of an iron cycle, wheres Mo may be used as a proxy for strongly reducing conditions in the water column.

\section{ACKNOWLEDGMENTS}

We thank A. Zwyssig and G. Friedl for help with field work, E. Grieder and D. Kistler for help in the laboratory and G. Friedl, M. Mengis, B. Müller, H. Weissert and A. Wüest for fruitful discussions. The advice of M. Sturm during different stages of the project is gratefully acknowledged. This work was supported the Swiss National Science Foundation through NFP-31 (project 4031-33147).

\section{REFERENCES}

Aggett, J. and G. A. O'Brien, 1985. Detailed model for the mobility of arsenic in lacustrine sediments based on measurements in Lake Ohakuri. Environ. Sci. Technol. 19:231-238.

Baccini, P. and T. Joller, 1981. Transport processes of copper and zinc in a highly eutrophic and meromictic lake. Schweiz. Z. Hydrol. 43 (1):176-199.

Baes, C. I. and R. E. Mesmer, 1976. The hydrolysis of cations. New York, John Wiley.

Balistrieri, L. S., J. W, Murray and B. Paul, 1992 a. The biochemical cycling of trace metals in the water column of Lake Sammamish, Washington: Response to seasonally anoxic conditions. Limnol. Oceanogr. 37:529-548.

Balistrieri, L. S., J. W. Murray and B. Paul, 1992 b. The cycling of iron and manganese in the watercolumn of Lake Sammamish, Washington. Limnol. Oceanogr. 37:510-528.

Balistrieri, L. S., J. W. Murray and B. Paul, 1994. The geochemical cycling of trace metals in a biogenic meromictic lake. Geochim. Cosmochim. Acta 58 (19):3993-4008.

Belzile, N. and A. Tessier, 1990. Interactions between arsenic and iron oxyhdroxides in lacustrine sediments. Geochim. Cosmochim. Acta 54:102-109.

Benjamin, M. M.and B.D. Honeyman, 1992. Trace metals. In: Global biogeochemical cycles (Eds.) S. S. Butcher, R. J. Charlson, G. H. Orians and G. V. Wolfe, pp: 317-351. London, Academic Press.

Berang, P. G. and E. V. Grill, 1974. The effect of manganese oxide scavenging on molybdenum in Saanich Inlet, British Columbia. Marine Chemistry 2:125-148.

Berner, E. K. B. and R. A. Berner, 1996. Global environment. Water, Air and geochemical cycles. New Jersey, Prentice Hall.

Calvert, S. E. and T. F. Pedersen, 1993. Geochemistry of recent oxic and anoxic marine sediments: Implications for the geological record. Marine Geology 113:67-88.

Cullen, W. R. and K. J. Reimer, 1989. Arsenic speciation in the environment. Chem. Rev. 89:713-764.

Davison, W., 1993. Iron and Manganese in lakes. Earth-Science Reviews 34:119-163.

Davison, W. and R. R. De Vitre, 1992. Iron particles in freshwater. In: Environmental particles (Eds.) J. Buffle and Leeuwen, H. P., pp: 426-453. Boca Raton, Lewis Publishers.

De Vitre, R. R., B. Sulzberger and J. Buffle, 1994. Transformations of iron at redox boundaries. In: Chemical and biological regulations of aquatic systems (Eds.) J. Buffle and R. R. De Vitre, pp: 91-138. Boca Raton, Lewis Publishers.

Dzombak, d. A. and F. M. Morel, 1990. Surface Complexation Modeling. New York, Wiley.

Emerson, S., 1976. Early diagenesis in anaerobic lake sediments: Chemical equilibria in interstitial waters. Geochim. Cosmochim. Acta 40:925-934.

Emerson, S. R. and S. S. Huested, 1991. Ocean anoxia and the concentrations of molybdenum and vanadium in seawater. Marine Chemistry 34:177-196.

Friedl, G., B. Wehrli and A. Manceau, 1996. The role of solids in the cycling of manganese in eutrophic lakes - New insights from EXAFS-spectroscopy. Geochim. Cosmochim. Acta 61: $275-290$.

Hamilton-Taylor, J. and W. Davison, 1995. Redox-Driven Cycling of Trace Elements in Lakes. In: Physics and Chemistry in Lakes (Eds.) A. Lerman, D. M. Imboden and J. Gat, pp: 217-258. New York, Springer. 
Huerta-Diaz, M. A. and J. W. Morse, 1992. Pyritization of trace metals in anoxic marine sediments. Geochim. Cosmochim. Acta 56:2681-2702.

Johnson, C. A., L. Sigg and U. Lindauer, 1992. The chromium cycle in a seasonally anoxic lake. Limnol. Oceanogr. 37 (2):315-321.

Kelts, K., U. Briegel, K. Ghilarde and K. Hsu, 1986. The limnology-ETH coring system. Schweiz. Z. für Hydrologie 48:104-115.

Kreyszig, E., 1975. Statistische Methoden und ihre Anwendungen. Göttingen, Vandenhoeck und Ruprecht.

Lapp, B. and W. Balzer, 1993. Early diagenesis of trace metals as an indicator of past productivity changes in coastal sediments. Geochim. Cosmochim. Acta 57:4639-4652.

Magyar, B., H. C. Moor and L. Sigg, 1993. Vertical distribution and transport of molybdenum in a lake with seasonal anoxic hypolimnion. Limnol. Oceanogr. 38:521-531.

Niessen, F. and M. Sturm, 1987. Die Sedimente des Baldeggersees (Schweiz) - Ablagerungsraum und Eutrophierungsentwicklung während der letzten 100 Jahre. Arch. Hydrobiol. 108:365-383.

Nipkow, F., 1928. Über das Verhalten der Skelette planktischer Kieselalgen in geschichtetem Tiefenschlamm des Zürich- und Baldeggersees. Schweiz. Z. Hydrol. 4:71-120.

Peeters, F., A. Wüest, G. Piepke and D. M. Imboden, 1996. Horizontal mixing in lakes. J. Geophys. Res. 101 (C8):18361-18375.

Pilipchuck, M. F. and I. I. Volkov, 1974. Behavior of molybdenum in processes of sediment formation and diagenesis. In: The Black Sea: Geology, chemistry and biology (Eds.) E. T. Degens and D. A. Ross, pp: 542-552. Am. Assoc. Petrol. Geol. Mem.

Richard, F. C. and A. C. M. Bourg, 1991. Aqueous geochemistry of chromium: a review. Water Res. 25:807-816.

Rudnicki, M. D. and H. Elderfield, 1993. A chemicial model of the bouyant and neutrally buoyant plume above the TAG vent field, 26 degrees N, Mid-Atlantic Ridge. Geochim. Cosmochim. Acta 57:2939-2957.

Schaller, T., H. C. Moor and B. Wehrli, 1997. Sedimentary profiles of Fe, Mn, V, Cr, As and Mo as indicators of benthic redox conditions in Baldeggersee. Aquatic Sciences 59:345-361.

Schaller, T. and B. Wehrli, 1997. Geochemical focusing of manganese in lake sediments. An indicator of deep water oxygen conditions. Aquatic Geochemistry 2:359-378.

Seyler, P. and J. M. Martin, 1989. Biogeochemical processes affecting arsenic distribution in a permanently stratified lake. Environ. Sci. Technol. 23:1258-1263.

Shaw, T. J., J. M. Gieskes and R. A. Jahnke, 1990. Early diagenesis in differing depositional environments: The response of transition metals in pore water. Geochim. Cosmochim. Acta 54:1233-1246.

Sigg, L., 1994. Regulation of trace elements in lakes: The role of sedimentation. In: Chemical and biological regulations of aquatic systems. (Eds.) J. Buffle and De Vitre, R. R., pp: 199232. Lewis Publishers.

Sigg, L., M. Sturm and D. Kistler, 1987. Vertical transport of heavy metals by settling particles in Lake Zürich. Limnol. Oceanogr. 32 (1):112-130.

Stadelmann, P., T. Joller and D. M. Imboden, 1984. Die Auswirkungen von internen Massnahmen im Baldeggersee: Zwangszirkulation und Sauerstoffbegasung des Hypolimnions. Verh. Internat. Verein. Limnol. 22:1052-1065.

Sugawara, K., S. Okabe and M. Tanaka, 1961. Geochemistery of molybdenum in natural waters (II). J. Earth Science Ngoya Univ. 9:114-128.

Tessier, A., 1992. Sorption of trace elements on natural particles in oxic environments. In: Environmental particles. (Eds.) J. Buffle and Leeuwen, H. P., pp: 426-453. Boca Raton, Lewis Publishers.

Thomson, J., N. C. Higgs, I. W. Croudace, S. Colley and D. J. Hydes, 1993. Redox zonation of elements at an oxic/postoxic boundary in deep-sea sediments. Geochim. Cosmochim. Acta 57:579-595.

Thomson, J., N. C. Higgs, T. R. S. Wilson, G. J. DeLange and P. J. M. Van Santvoort, 1995. Redistribution and geochemical behaviour of redox-sensitive elements around S1m the most recent eastern Mediterranean sapropel. Geochim. Cosmochim. Acta 59:3487-3501.

Turner, D. R., M. Whitfield and A. G. Dickson, 1981. The equilibrium speciation of dissolved components in freshwater and seawater at $25^{\circ} \mathrm{C}$ and $1 \mathrm{~atm}$ pressure. Geochim. Cosmochim. Acta $45: 855-881$. 
Urban, N. R., C. Dinkel and B. Wehrli, 1997. Solute transfer across the sediment surface of a eutrophic lake: I. Porewater profiles from dialysis samplers. Aquat. Sci. 59:1-25.

Wanty, R. B. and M. B. Goldhaber, 1992. Thermodynamics and kinetics of reactions involving vanadium in natural systems: Accumulation of vanadium in sedimentary rocks. Geochim. Cosmochim. Acta 56:1471-1483.

Wehrli, B., 1900. Redox Reactions of Metal Ions at Mineral Surfaces. in: Aquatic Chemical Kinetics. (Ed. w. Stumm) pp: 311-336. New York, John Wiley.

Wehrli, B., A. F. Lotter, T. Schaller and M. Sturm, 1997. High-resolution varve studies in Baldeggersee (Switzerland): project overview and limnological background data. Aquatic Sciences 59:285-294.

Wehrli, B. and W. Stumm, 1989. Vanadyl in natural waters: Adsorption and hydrolysis promote oxygenation. Geochim. Cosmochim. Acta 53:69-77.

Wüest, A., D. C. van Senden, J. Imberger, G. Piepke and M. Gloor, 1996. Comparison of diapycnal diffusivity measured by tracer and microstructure techniques. Dynamics of atmospheres and oceans 24:27-39.

Züllig, H., 1982. Untersuchungen über die Stratigraphie von Carotiniden im geschichteten Sediment von 10 Schweizer Seen zur Erkundung früherer Phytonplankton-Entfaltungen. Schweiz. Z. Hydrol. 44 (1):1-98.

Received 8 January 1997;

revised manuscript accepted 27 August 1997. 